\title{
Остапенко С.И.
}

\author{
Алгоритмическая деятельность будущих учителей \\ в процессе дистанционного обучения как фактор \\ повышения качества образования
}

\author{
Ostapenko S.I. \\ The algorithmic activity of future teachers in the process of distance \\ learning as a factor of improving the quality of education
}

В статье обосновывается значимость формирования алгоритмической деятельности будущих учителей в процессе дистанционного обучения. Профессиональное и личностное становление учителя зависит от уровня сформированности данного вида деятельности, способствуя быстрой ориентации в учебном материале. Это обстоятельство важно для будущего учителя, как в процессе дистанционного обучения, так и для последующей его педагогической деятельности

Ключевые слова: алгоритмическая деятельность, алгоритм, будущие учителя, дистанционное обучение

\section{Остапенко Светлана Ивановна}

Кандидат педагогических наук, старший преподаватель

Белгородский государственный национальный исследовательский университет

г. Белгород, ул. Победы, 85

\begin{abstract}
The article explains the importance of building the algorithmic activity of future teachers in the process of distance learning. Professional and personal development of teachers depends on the level of formation of this type of activity, facilitating quick orientation in the training material. This circumstance is important for the future teachers in the process of distance learning, and subsequent teaching
\end{abstract}

Key words: algorithmic activity, algorithm, future teachers, distance learning

\author{
Ostapenko Svetlana Ivanovna \\ Candidate of Pedagogic Sciences, Senior teacher \\ Belgorod national research university \\ Belgorod, Pobedy st., 85
}

Главным звеном в направлении развития образования является организация у студентов учебного настроя, а также наделение умениями учиться, научение самостоятельной деятельности с применением перспективных средств информационных технологий. Данная тенденция связана с процессом дистанционного обучения, которое позволяет будущим учителям в индивидуальном темпе изучать материал, выполнять практические задания, требования к зачетам и экзаменам. Для этого необходимо четко распределять свои учебные действия, планировать деятельность, т.е. уметь решать задачи не только по предложенным алгоритмам, но и составлять собственные алгоритмы, более оптимальные для выполнения того или иного задания. Такой подход 
становится возможен, если перенаправить студента из пассивного потребителя знаний в активного их творца, который способен обозначить проблему, найти варианты ее решения, прийти к оптимальному результату. Перед учителем всегда стоит вопрос: как учить учеников, чтобы они не только получали знания, но и умели думать? Надо стараться формировать у учащихся достаточно общие методы мышления и деятельности, общие способы подхода к любой задаче. Алгоритм является одним из видов общих методов деятельности вообще, а не только умственной деятельности. Особую роль в процессе профессионального саморазвития учителя играет его готовность к новому, передовому, а именно умение алгоритмировать свою деятельность и действия учеников. Чтобы вырастить новое поколение детей, учитель должен быть другой формации, быть эрудированным и гибким в поведении, уметь применять готовые и составлять собственные алгоритмы действий на каждом этапе профессионально-педагогической деятельности.

Под алгоритмической деятельностью понимается деятельность, целью которой является создание, понимание и преобразование алгоритма, который является и предметом, и непосредственным продуктом этой деятельности. Алгоритмически культурный учитель умеет определить сущность и рамки своих профессиональных потребностей, эффективно и рационально осуществляет создание новых алгоритмов своей деятельности [2].

Актуальность организации учебного процесса с использованием дистанционных технологий определяется тем, что, в настоящее время, на первое место выходит не просто процесс получения знаний, но и умение применять эти знания для решения разнообразных профессионально-педагогических задач. Особую значимость в данных условиях приобрела подготовка будущих учителей, так как педагог в своей профессиональной деятельности может выступать в разных ролях: консультанта, администратора, эксперта и т.п. В процессе дистанционного обучения от будущего учителя требуются новые знания и умения, особый стиль мышления, обеспечивающие необходимую социальную адаптацию к переменам и гарантирующие достойное место в информационной среде, ответственность за выбор режима учебной деятельности, формирование умений осуществлять алгоритмическую деятельность, а также знаний, необходимых для спланированного продвижения в учении. Процесс дистанционного обучения при организации самостоятельной деятельности студентов предоставляет возможность: организовать оперативную консультацию; обеспечить интерактивную деятельность; создать условия для осуществления алгоритмической деятельности; развивать умения рационализировать учебную деятельность; формировать навыки само- и взаимоконтроля результатов деятельности с целью эффективного решения педагогических задач.

И.Р. Ишутина понимает готовность студентов - будущих учителей к алгоритмической деятельности в их профессиональной деятельности как интегративное качество учителя, содержащее в себе знания сущности целостного педагогического процесса с использованием компьютерных технологий, алгоритмических программ, умение осуществлять работу по их созданию и применению в учебном процессе [1]. Дистанционное обучение предоставляет воз- 
можность для будущих учителей по алгоритмам разработать собственные идеи и представить их почти в готовом виде в сети.

Алгоритмическая деятельность будущих учителей в процессе дистанционного обучения предполагает, чтобы студенты не только знакомились с общими основами алгоритмов, но и научились видеть в конкретных алгоритмических объектах их общие и специфические свойства, чтобы у них формировались умения переносить общие знания с одного объекта на другой.

Целью подготовки студентов в процессе дистанционного обучения является не только привитие им элементарной алгоритмической грамотности, но и освоение будущими учителями тех знаний и умений, которые позволят им решать творчески решать задачу изучения и использования алгоритмов в процессе обучения для оптимального развития учащихся [3]. В то же время такие задачи решаются успешнее, если задается алгоритм действий учителя и деятельности учеников. Использование алгоритмов в обучении оказывает содействие осознанию умственных и практических операций; умению их выделить, анализировать, проверять и находить из различных приемов действий наиболее рациональные.

Может показаться, что работа по алгоритму далека от творческой, что в ней происходит лишь репродуцирование действий по предложенному образцу. Необходимо отметить, что даже явная имитация алгоритмизированных действий предполагает не воспроизведение информации, а самостоятельную творческую деятельность, но в рациональной и целесообразной последовательности. Алгоритмизированной является только последовательность действий, но не само содержание поставленной задачи, поэтому механическая работа не может иметь место в алгоритмической деятельности. Концентрируясь на операциональной технологичности алгоритмических действий, студент постигает логику движения мысли от поставленной цели деятельности до ее творческой реализации. По достижению мысли, заложенной в алгоритме, самостоятельное составление алгоритма можно приравнять к созданию проекта модели решения педагогической творческой задачи, поскольку каждый шаг алгоритма предполагает переход к иному структурному типу деятельности. Алгоритмизация в условиях дистанционного обучения, с одной стороны, позволяет студентам осознать технологию творческого процесса в будущей профессионально-педагогической деятельности, с другой - с индивидуальной траекторией темпа и глубины овладения ею «вписываться» в информационнотворческую деятельность как субъекты самоуправления.

Таким образом, в модернизации обучения в профессиональной подготовке будущих учителей алгоритмическая деятельность обеспечивает формирование основ алгоритмизации педагогической деятельности, отражает способ самоорганизации деятельности в информационном обществе и, следовательно, развивает у них фундаментальное образование, что очень востребовано современным учителем для углубленного и содержательного преподавания в школе. Алгоритмическая деятельность в процессе дистанционного обучения будущего учителя как сформированная система алгоритмических знаний и навыков, и умение использовать их в различных условиях профессионально- 
педагогической деятельности является важным фактором повышения качества образования.

\section{Список используемых источников:}

1. Ишутина И.Р. Педагогические условия формирования у будущих учителей информатики готовности к применению компьютерных обучающих программ // Информатика и образование. 2008. № 8. C. 87-88.

2. Остапенко С.И. Формирование алгоритмической культуры будущих учителей в процессе дистанционного обучения: дис. канд. пед. наук: 13.00.08. Белгород, 2013. 175 c.

3. Беликов В.А. и др. Профессиональное образование. Методология деятельности. М.: Владос, 2009. $334 c$.

(C) 2015, Остапенко С.И.

Алгоритмическая деятельность будущих учителей в процессе дистанционного обучения как фактор повышения качества образования
(C) 2015, Ostapenko S.I.

The algorithmic activity of future teachers in the process of distance learning as a factor of improving the quality of education 